\title{
Evaluation of soil moisture in CMIP5 simulations over the contiguous United States using in situ and satellite observations
}

\author{
Shanshui Yuan ${ }^{1}$ and Steven M. Quiring ${ }^{2}$ \\ ${ }^{1}$ Climate Science Lab, Department of Geography, Texas A\&M University, College Station, TX 77843, USA \\ ${ }^{2}$ Atmospheric Sciences Program, Department of Geography, Ohio State University, Columbus, OH 43210, USA \\ Correspondence to: Shanshui Yuan (yuanshanshui@tamu.edu)
}

Received: 12 September 2016 - Discussion started: 9 November 2016

Revised: 1 March 2017 - Accepted: 2 April 2017 - Published: 24 April 2017

\begin{abstract}
This study provides a comprehensive evaluation of soil moisture simulations in the Coupled Model Intercomparison Project Phase 5 (CMIP5) extended historical experiment (2003 to 2012). Soil moisture from in situ and satellite sources is used to evaluate CMIP5 simulations in the contiguous United States (CONUS). Both near-surface (0$10 \mathrm{~cm})$ and soil column $(0-100 \mathrm{~cm})$ simulations from more than 14 CMIP5 models are evaluated during the warm season (April-September). Multimodel ensemble means and the performance of individual models are assessed at a monthly timescale. Our results indicate that CMIP5 models can reproduce the seasonal variability in soil moisture over CONUS. However, the models tend to overestimate the amount of both near-surface and soil column soil moisture in the western US and underestimate it in the eastern US. There are large variations across models, especially for the near-surface soil moisture. There are significant regional variations in performance as well. Results of a regional analysis show that in the deeper soil layers, the CMIP5 soil moisture simulations tend to be most skillful in the southern US. Based on both the satellite-derived and in situ soil moisture, CESM1, CCSM4 and GFDL-ESM2M perform best in the $0-10 \mathrm{~cm}$ soil layer and CESM1, CCSM4, GFDL-ESM2M and HadGEM2-ES perform best in the $0-100 \mathrm{~cm}$ soil layer.
\end{abstract}

\section{Introduction}

Soil moisture plays a critical role in hydrological processes, land-atmosphere interactions and climate variability. Through controlling water mass transfer, soil moisture affects runoff (Penna et al., 2011; Latron and Gallart,
2008; Zhang et al., 2001) and evapotranspiration (Wetzel and Chang, 1987; Vivoni et al., 2008; Detto et al., 2006). Soil moisture also influences the surface energy balance by affecting latent heat and ground fluxes (Ek and Holtslag, 2004; Ford and Quiring, 2014a). Soil moisture is one of the direct measures of drought used to assess future drought conditions in the latest IPCC report (Hartmann et al., 2013). Therefore, accurate soil moisture simulation is useful for many applications.

There are three main types of soil moisture data: in situ observations, remote sensing observations and model simulations. In situ observations provide point measurements at a variety of depths. The spatial and temporal coverage of in situ observations is quite limited and each in situ network may utilize different instruments and calibration techniques. These factors make it more challenging to use in situ soil moisture; however, recent developments have improved the utility of these measurements. For example, the International Soil Moisture Network (ISMN; Dorigo et al., 2011), which was initiated in 2010 , collects in situ soil moisture from more than 1400 stations internationally and provides quality-controlled hourly-to-weekly soil moisture data. The North American Soil Moisture Database (NASMD; Quiring et al., 2016) provides quality-controlled daily soil moisture from approximately 1800 stations, most of which are located in the United States. NASMD has been used for validating the North American Land Data Assimilation System (NLDAS; Xia et al., 2015b, a) and examining the nature of land-atmosphere interactions (Ford et al., 2015b, c; Wang et al., 2015). There are numerous other studies that use in situ soil moisture from NASMD and ISMN. Ford and Quiring (2014a) used quantile regression to examine the relation- 
ship between in situ soil moisture and extreme temperature in Oklahoma. They found the soil moisture anomalies can be used for predicting the percentage of hot days in the following month. Ford et al. (2015a) found that soil moisture can also be used to better predict the onset of flash drought events in Oklahoma. Brocca et al. (2013) found in situ soil moisture can be used to improve daily precipitation estimation at the catchment scale.

Soil moisture observations from satellite remote sensing, such as the Soil Moisture and Ocean Salinity (SMOS) mission (Kerr et al., 2001), NASA's Aquarius (Le Vine et al., 2007) and Soil Moisture Active-Passive (SMAP) missions (Brown et al., 2013), can provide global soil moisture data. Previous studies have shown that satellite-derived soil moisture can accurately capture the annual cycle (Albergel et al., 2012b; Brocca et al., 2011); however, the accuracy of the satellite-derived soil moisture varies significantly both geographically and from product to product (Fang et al., 2016; Wanders et al., 2012). Rötzer et al. (2015) investigated the spatial and temporal behavior of the SMOS and the MetOpA Advanced Scatterometer (ASCAT) soil moisture. They demonstrated that SMOS is more strongly affected by temporally invariant factors, such as topography and soil properties, while ASCAT soil moisture is influenced by temporally variant factors, such as precipitation and evaporation. To overcome the limitations of satellite-derived soil moisture estimates, assimilated satellite products have been developed. Renzullo et al. (2014) used the ensemble Kalman filter method to assimilate the Advanced Microwave Scanning Radiometer for EOS (AMSR-E) and ASCAT-derived soil moisture. They found that data assimilation can significantly improve the accuracy of root-zone soil moisture estimates. A merged soil moisture product from active and passive sensors was released by the European Space Agency (ESA) in 2010 (Liu et al., 2011). This is a part of the European Space Agency Programme on Global Monitoring of Essential Climate Variables (ECVs), and hereafter it will be referred to as ECV soil moisture. ECV soil moisture has been validated globally (Dorigo et al., 2015) and in regional studies in places such as in China (An et al., 2016) and east Africa (McNally et al., 2016). One of the primary limitations of satellite-based approaches is that they can typically only measure water in the top few centimeters of the soil (Crow et al., 2012).

Model simulation from land surface models (Koster et al., 2009) and fully coupled general circulation models (GCMs; Srinivasan et al., 2000) is another source of spatially continuous soil moisture at a variety of depths. However, validation studies have shown that these models can have significant biases. Guo and Dirmeyer (2006) compared 11 land surface models from the Second Global Soil Wetness Project (GSWP-2) and found that although models can reproduce soil moisture anomalies, they do not accurately simulate the absolute soil water content. Xia et al. (2015b) evaluated four land surface models within the North American Land Data Assimilation System Project Phase 2 (NLDAS-
2). They concluded that Noah and VIC models are wetter, while Mosaic and SAC are drier. Compared with land surface models, coupled GCMs are more commonly used to investigate soil moisture-atmosphere interactions (Seneviratne et al., 2010). Koster et al. (2004) is a benchmark study of soil moisture-temperature and soil moisture-precipitation coupling strength using 12 GCMs in the Global LandAtmosphere Coupling Experiment (GLACE). They identified three global "hot spots" where one finds strong landatmosphere coupling. However, they also demonstrated that there are substantial inconsistencies in coupling strength between models. van den Hurk et al. (2010) used realistic soil moisture initializations in the second phase of GLACE (GLACE-2) to improve the forecast skill of summertime temperature and precipitation in Europe.

In 2012, the fifth phase of the Coupled Model Intercomparison Project (CMIP5) was completed to provide a stateof-the-art multimodel dataset for advancing the knowledge of climate variability and climate change (Taylor et al., 2012). $\mathrm{Li}$ et al. (2007) concluded, based on previous versions of the CMIP models, that these models have difficulties to accurately simulate the seasonal cycle of soil moisture. They also found that improved simulation of solar radiation and precipitation leads to more accurate soil moisture simulations. Although the CMIP5 models have been used to investigate land-atmosphere interactions (Dirmeyer et al., 2013; Seneviratne et al., 2013; May et al., 2015; Lorenz et al., 2016), to date, there has not been a comprehensive evaluation of the accuracy of the CMIP5 soil moisture simulations in the United States. Therefore, this paper will address this knowledge gap.

In this study, we evaluate CMIP5 soil moisture simulations in two soil layers $(0-10$ and $0-100 \mathrm{~cm})$ over the contiguous United States (CONUS) using in situ and satellite-derived soil moisture. We evaluate both individual models and the multimodel ensemble mean using in situ soil moisture from 363 sites as well as satellite observations. A description of the data and methods used in this study is presented in Sect. 2. This is followed by the presentation of the results and a discussion in Sect. 3, and the limitations and conclusions of the study are summarized in Sects. 4 and 5, respectively.

\section{Data and methods}

\subsection{Study regions}

We evaluate the CMIP5 soil moisture simulations over CONUS and in eight subregions (Fig. 1). These subregions were defined using a land cover classification from US Geological Survey (Loveland et al., 2000). These subregions (dashed boxes in Fig. 1) were utilized by Notaro et al. (2006) and they have been applied in other land-atmosphere studies (Mei and Wang, 2012; Sanchez-Mejia et al., 2014; Wu and Zhang, 2013). In this study, we made some small adjustments to these subregions so that they included more in situ sites 
Table 1. List of 17 CMIP5 models in this study.

\begin{tabular}{|c|c|c|c|c|}
\hline \multirow[b]{2}{*}{ Model name } & \multirow[b]{2}{*}{ Model center (or groups) } & \multirow[b]{2}{*}{ Spatial resolution } & \multicolumn{2}{|c|}{ Soil moisture simulation } \\
\hline & & & $0-10 \mathrm{~cm}$ & $0-100 \mathrm{~cm}$ \\
\hline ACCESS 1.3 & $\begin{array}{l}\text { Commonwealth Scientific and Industrial Research Organization (CSIRO) } \\
\text { and Bureau of Meteorology (BOM), Australia }\end{array}$ & $145 \times 192$ & $\sqrt{ }$ & $\sqrt{ }$ \\
\hline BCC-CSM1.1 & Beijing Climate Center, China Meteorological Administration & $64 \times 128$ & $\sqrt{ }$ & $\sqrt{ }$ \\
\hline BNU-ESM & College of Global Change and Earth System Science, Beijing Normal University & $64 \times 128$ & $\sqrt{ }$ & $\sqrt{ }$ \\
\hline CanESM2 & Canadian Centre for Climate Modelling and Analysis & $64 \times 128$ & $\sqrt{ }$ & $\sqrt{ }$ \\
\hline CCSM4 & National Center for Atmospheric Research & $192 \times 228$ & $\sqrt{ }$ & $\sqrt{ }$ \\
\hline CESM1(CAM5) & Community Earth System Model Contributors & $192 \times 228$ & $\sqrt{ }$ & $\sqrt{ }$ \\
\hline CNRM-CM5 & $\begin{array}{l}\text { Centre National de Recherches Météorologiques and } \\
\text { Centre Européen de Recherche et Formation Avancée en Calcul Scientifique }\end{array}$ & $192 \times 228$ & $\sqrt{ }$ & $\sqrt{ }$ \\
\hline CSIRO-MK3.6.0 & $\begin{array}{l}\text { Commonwealth Scientific and Industrial Research Organization in } \\
\text { collaboration with Queensland Climate Change Centre of Excellence }\end{array}$ & $96 \times 192$ & $\sqrt{ }$ & \\
\hline FGOALS-g2 & LASG, Institute of Atmospheric Physics, Chinese Academy of Sciences & $60 \times 128$ & $\sqrt{ }$ & $\sqrt{ }$ \\
\hline GFDL-ESM2M & NOAA Geophysical Fluid Dynamics Laboratory & $90 \times 144$ & $\sqrt{ }$ & $\sqrt{ }$ \\
\hline GISS-E2-H & NASA Goddard Institute for Space Studies & $90 \times 144$ & $\sqrt{ }$ & $\sqrt{ }$ \\
\hline HadGEM2-ES & $\begin{array}{l}\text { Met Office Hadley Centre (additional realizations } \\
\text { contributed by Instituto Nacional de Pesquisas Espaciais) }\end{array}$ & $145 \times 192$ & $\sqrt{ }$ & $\sqrt{ }$ \\
\hline INM-CM4 & Institute for Numerical Mathematics & $120 \times 180$ & $\sqrt{ }$ & $\sqrt{ }$ \\
\hline IPSL-CM5A-LR & Institut Pierre-Simon Laplace & $96 \times 96$ & $\sqrt{ }$ & \\
\hline MIROC-ESM & $\begin{array}{l}\text { Japan Agency for Marine-Earth Science and Technology Atmosphere } \\
\text { and Ocean Research Institute (The University of Tokyo) } \\
\text { and National Institute for Environmental Studies }\end{array}$ & $64 \times 128$ & $\sqrt{ }$ & $\sqrt{ }$ \\
\hline MRI-CGCM3 & Meteorological Research Institute & $160 \times 320$ & $\sqrt{ }$ & \\
\hline NorESM1-M & Norwegian Climate Centre & $96 \times 144$ & $\sqrt{ }$ & $\sqrt{ }$ \\
\hline
\end{tabular}

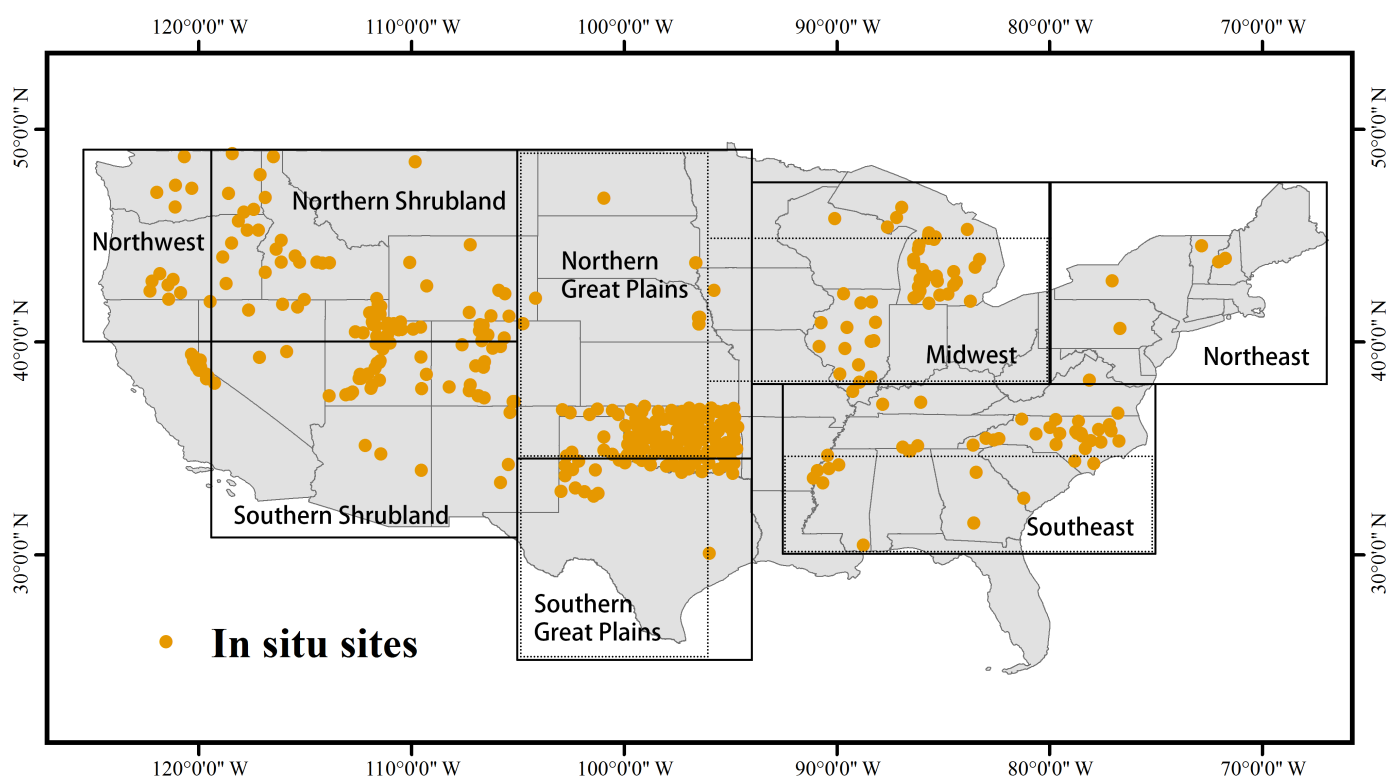

Figure 1. Spatial distribution of in situ soil moisture stations and the boundaries of the eight subregions.

(solid boxes in Fig. 1). The eight subregions are the Midwest (MW: $38-47.5^{\circ} \mathrm{N}, 94-80^{\circ} \mathrm{W}$ ), Northeast (NE: $38-47.5^{\circ} \mathrm{N}$, $80-67^{\circ} \mathrm{W}$ ), Northern Great Plains (NGP: $34.4-49^{\circ} \mathrm{N}, 105-$ $94^{\circ} \mathrm{W}$ ), Northern Shrubland (NS: $40-49^{\circ} \mathrm{N}, 119.4-105^{\circ} \mathrm{W}$ ), Northwest (NW: $40-49^{\circ} \mathrm{N}, 124-119.4^{\circ} \mathrm{W}$ ), Southeast (SE: $30-38^{\circ} \mathrm{N}, 92.5-75^{\circ} \mathrm{W}$ ), Southern Great Plains (SGP: $25-$ $\left.34.4^{\circ} \mathrm{N}, 105-94^{\circ} \mathrm{W}\right)$ and Southern Shrubland (SS: 30.8$\left.40^{\circ} \mathrm{N}, 119.4-105^{\circ} \mathrm{W}\right)$.

\subsection{CMIP5 models}

All the Earth system models (ESMs) in the CMIP5 archive that have soil moisture data are evaluated in this study. We evaluate monthly near-surface $(0-10 \mathrm{~cm})$ soil moisture from 
17 ESMs and soil column $(0-100 \mathrm{~cm})$ soil moisture from 14 ESMs that are part of the CMIP5 archive (Table 1). Our analysis uses data from 2003 to 2012 because more in situ sites are available in this 10-year time period. Although the traditional CMIP5 experiment ends in 2005, some ESMs, such as BCC-CSM1.1 and CanESM2, have an extended historical simulation through 2012. Therefore, we extend all the model simulations to 2012 by combining the 2006-2012 outputs from the future emission scenario, the Representative Concentration Pathways (RCP) 4.5, to the regular historical experiment outputs. RCP4.5 is a pathway for stabilization of radiative forcing at $4.5 \mathrm{~W} \mathrm{~m}^{-2}$ by 2100 (Thomson et al., 2011). A similar approach was adopted in the IPCC AR5 report (Bindoff et al., 2013). Jones et al. (2013) also used RCP4.5-forced CMIP5 simulations from 2005 to 2010 to investigate near-surface temperature variations. To validate this approach, we compared simulated precipitation based on different RCP scenarios with the Climatic Research Unit (CRU) precipitation in CONUS from 2006 to 2012 (results not shown) and found that the RCP4.5 simulations closely match the CRU observations.

Because all of the ESMs have a different spatial resolution, model output is regridded to a uniform resolution of $0.25^{\circ} \times 0.25^{\circ}$ using a bilinear interpolation method. This resolution was chosen to match the spatial resolution of the satellite observations. Bilinear interpolation is a common method for interpolating precipitation (Chen and Frauenfeld, 2014; Hsu et al., 2013; Qu et al., 2013). Crow et al. (2012) demonstrated that large-scale spatial patterns of soil moisture are dominated by precipitation. Therefore, we believe that the bilinear interpolation method is an appropriate method.

\subsection{In situ observations}

Daily in situ soil moisture data from 2003 to 2012 were obtained from North American Soil Moisture Database (http: //soilmoisture.tamu.edu/). The North American Soil Moisture Database archives data from a variety of national and state networks (Quiring et al., 2016). Data from 363 stations are used in this study (Fig. 1). These stations belong to eight observational networks, as shown in Table 2. Qualitycontrolled daily soil moisture data have been used to validate model simulations in previous studies (Xia et al., 2015c; Dirmeyer et al., 2016). In this study, any stations with short periods of missing data ( $<10$ days) are infilled using the daily average replacement (DAR) method (Ford and Quiring, 2014b). Soil moisture measurements at different depths are used to estimate the volumetric water content (VWC) in the top $10 \mathrm{~cm}$ and top $100 \mathrm{~cm}$ of the soil column. For example, the VWC measured at $5 \mathrm{~cm}$ is assumed to represent the VWC in $0-10 \mathrm{~cm}$ soil layer. When there are multiple soil moisture sensors within the top $100 \mathrm{~cm}$, the measurements are combined using a depth-weighted average. Daily soil moisture measurements are then averaged to a monthly value to match the temporal resolution of the ESMs. The in situ measure- ments are also aggregated spatially to facilitate comparison with the CMIP5 models. We use a simple spatial average to aggregate all of the stations within each $0.25^{\circ} \times 0.25^{\circ}$ grid cell. Then, all of the grid cells with stations in them are averaged to produce a regional or national dataset for comparing the in situ and modeled soil moisture. Although this spatial average method is not the optimal technique to reduce sampling errors (Crow et al., 2012), it is simple and has been widely used in previous model evaluations (Robock et al., 2003; Albergel et al., 2012a; Xia et al., 2015b). This approach reduces some of the bias associated with the pointversus-grid scale mismatch. Utilization of this approach over the entire CONUS provides general soil moisture conditions simulated by CMIP5 models over the CONUS. However, we are also interested in spatial variations in model performance. Therefore, we also evaluated model performance after dividing CONUS into eight subregions.

Measuring water content in frozen soils is a challenge (Xia et al., 2015c). Therefore, the CONUS analysis only evaluates the CMIP5 simulations during the warm season (AprilSeptember). For a regional evaluation, we use data from all the months in the three southern subregions (Southeast, Southern Great Plains and Southern Shrubland) where frozen soils do not occur. All other subregions only use data from the warm season.

\subsection{Satellite observations}

Satellite-derived soil moisture from the soil moisture climate change initiative (CCI) project (http: //www.esa-soilmoisture-cci.org/) is used in this study. This project is a part of the European Space Agency Programme on Global Monitoring of Essential Climate Variables (ECVs; Liu et al., 2012). ECV soil moisture is based on active and passive remote sensing data and it has been validated using reanalyses (Albergel et al., 2013a, b) and in situ observations (Pratola et al., 2014). The spatial resolution of monthly ECV soil moisture is $0.25^{\circ}$. ECV soil moisture is not available during the cold season in the northern United States. Therefore, similar to the in situ observations, only warm season evaluations are undertaken for CONUS and the five northern subregions. Data from all months are used in the three southern subregions.

\subsection{Evaluation metric}

Pearson correlation $(r)$, mean absolute error (MAE) and the coefficient of efficiency ( $E$; Legates and McCabe, 1999) are used to quantify the agreement between observations and model simulations. Taylor's skill score ( $S$; Taylor, 2001) is also used to measure the ability of individual CMIP5 models to reproduce the climatological soil moisture distribution. The equation of $S$ is shown as the following:

$$
S=\frac{4(1+R)}{[\sigma+(1 / \sigma)]^{2}\left(1+R_{0}\right)},
$$


Table 2. List of observational networks in this study.

\begin{tabular}{lrl}
\hline Network & $\begin{array}{r}\text { Number of sites } \\
\text { (used in this study) }\end{array}$ & Reference \\
\hline AmeriFlux & 4 & Baldocchi et al. (2001) \\
North Carolina Environment and Climate Observing Network & 24 & Pan et al. (2012) \\
Illinois Climate Network & 16 & Hollinger et al. (1994) \\
Michigan Automated Weather Network & 34 & Andresen et al. (2011) \\
Oklahoma Mesonet & 104 & Scott et al. (2013) \\
Soil Climate Analysis Network & 66 & Schaefer et al. (2007) \\
Snowpack Telemetry & 97 & Schaefer and Paetzold (2001) \\
West Texas Mesonet & 18 & Schroeder et al. (2005) \\
\hline
\end{tabular}
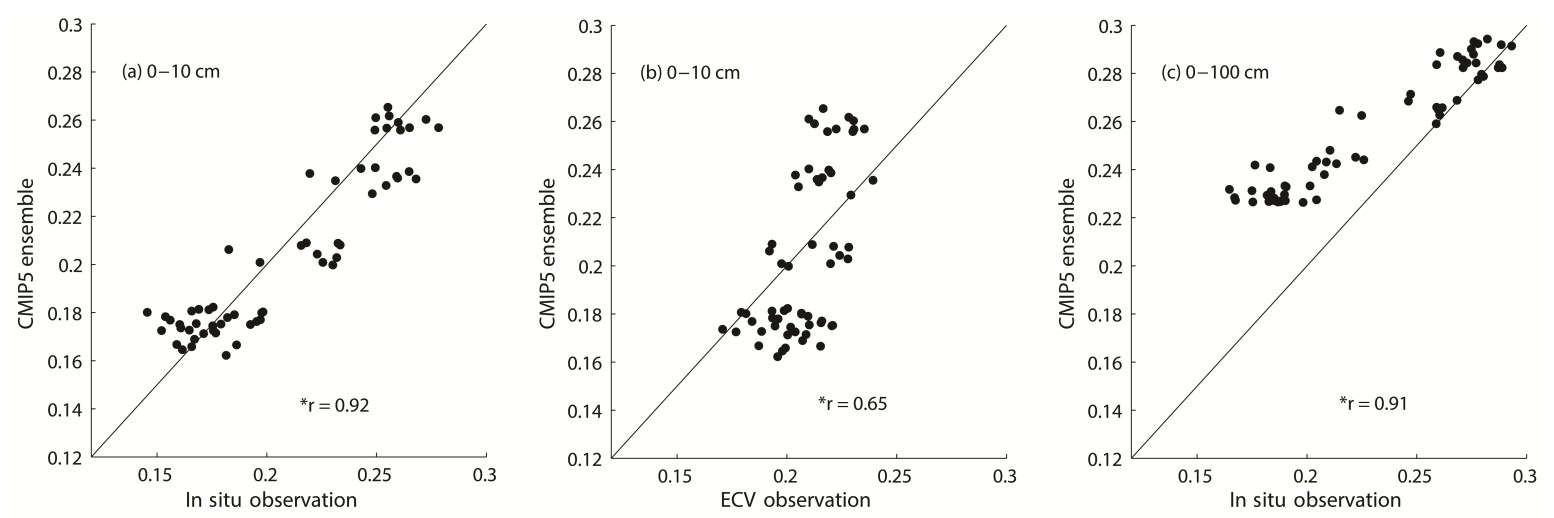

Figure 2. Comparison of soil moisture from the CMIP5 ensemble with in situ and satellite-derived (ECV) soil moisture. Each point represents monthly soil moisture data from the warm season (April to September) that have been spatially averaged over CONUS (2003-2012). Panel (a) indicates CMIP5 ensemble versus in situ observations in the $0-10 \mathrm{~cm}$ soil layer; (b) CMIP5 ensemble versus ECV in the 0-10 cm soil layer; (c) CMIP5 ensemble versus in situ observations in the 0-100 cm soil layer during the warm season (April to September).

where $R$ is the correlation between the simulated and observed soil moisture. $\sigma$ is the ratio of standard deviation of model simulation over standard deviation of observation and $R_{0}$ is the theoretical maximum correlation, equal to 1 .

\section{Results and discussion}

\subsection{Evaluation of model ensemble over CONUS}

Figure 2 shows the relationship between the CMIP5 ensemble mean and satellite-derived and in situ soil moisture during the warm season. All three of these datasets were averaged over CONUS. The multimodel ensemble mean is highly correlated with the in situ observations (Fig. 2a and c). The correlation $(r)$ between the in situ and model-derived soil moisture is 0.92 in the $0-10 \mathrm{~cm}$ soil layer and it is 0.91 in the $0-100 \mathrm{~cm}$ soil layer. Both of these correlations are statistically significant $(p<0.05)$. In the $0-100 \mathrm{~cm}$ soil layer, the CMIP5 soil water content is systematically higher than the in situ observations, especially during drier months (i.e., when soil water content is $<0.25 \mathrm{~cm}^{3} \mathrm{~cm}^{-3}$ ). Figure $2 \mathrm{~b}$ shows that there is a weaker relationship between the CMIP5 ensemble and ECV soil moisture and the correlation is only 0.65 . It appears that the variance of the satellite-derived soil moisture is much less than the CMIP5 ensemble. The ECV soil moisture only varies from $\sim 0.18$ to $0.24 \mathrm{~cm}^{3} \mathrm{~cm}^{-3}$, while CMIP5 varies from $\sim 0.16$ to $0.27 \mathrm{~cm}^{3} \mathrm{~cm}^{-3}$. Therefore, the ECV soil moisture tends to be systematically greater than CMIP5 during drier months and systematically lower than CMIP5 during wetter months.

We also examined the mean monthly soil moisture in the $0-10$ and $0-100 \mathrm{~cm}$ soil layers from April to September. Figure $3 \mathrm{a}$ shows the seasonal cycle in the $0-10 \mathrm{~cm}$ soil moisture for the in situ observations, ECV satellite data and CMIP5 models. Although there are substantial intermodel variations among the CMIP5 models, particularly with regards to the absolute soil water content, the CMIP5 ensemble (black line) shows strong agreement with in situ observations (red line). Both show that soil moisture decreases from April until August and then soil moisture recharge begins in September. Both the CMIP5 ensemble and the in situ observations have a similar seasonal cycle in terms of both the magnitude and timing. In comparison, the satellite-derived ECV soil mois- 

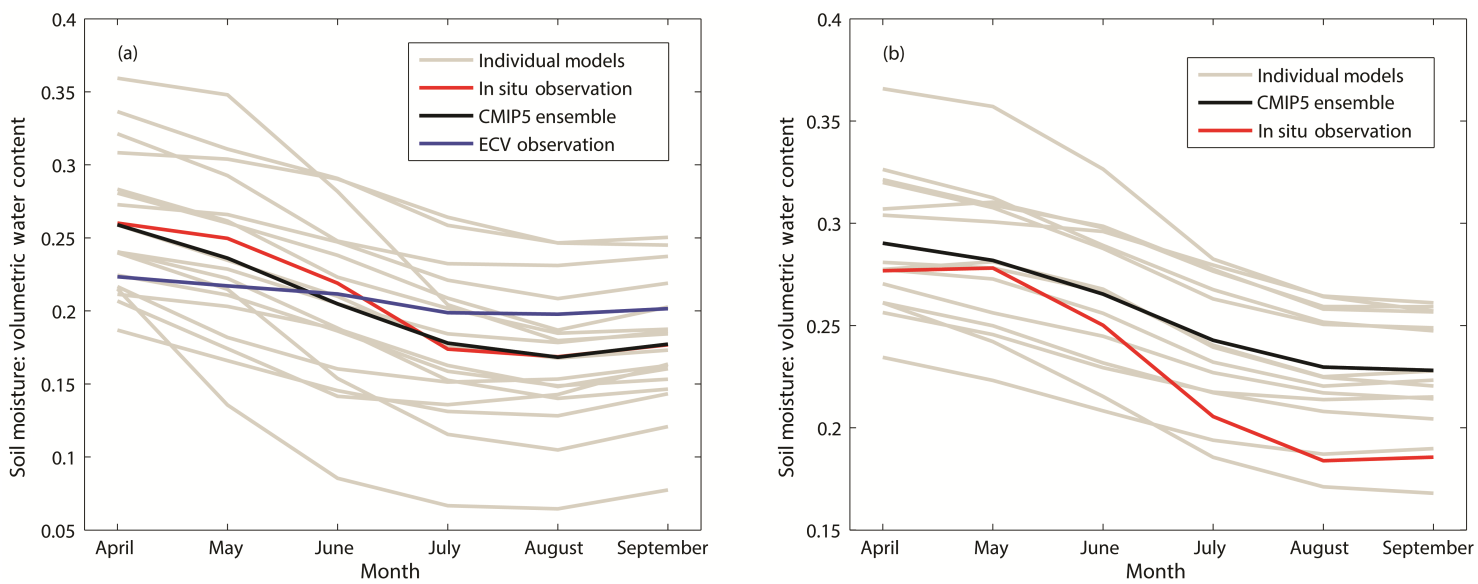

Figure 3. Mean monthly soil moisture (2003-2012) during the warm season (April to September) in the 0-10 cm soil layer (a) and in the 0-100 cm soil layer (b). Data are spatially averaged over CONUS. Figures show the monthly mean soil moisture from the in situ observations (red line), ECV satellite data (blue line), CMIP5 ensemble mean (black line) and the individual CMIP5 models (grey lines).

ture (blue line) shows little month-to-month variability and has a very weak seasonal cycle. Neither the timing nor the magnitude of these variations matches the in situ observations and the CMIP5 ensemble.

Figure $3 \mathrm{~b}$ shows the seasonal cycle in the $0-100 \mathrm{~cm}$ soil moisture for the in situ observations and the CMIP5 models. ECV soil moisture data are not shown since satellites are only able to estimate near-surface soil moisture. The seasonal cycle of soil moisture in the $0-100 \mathrm{~cm}$ layer is similar to the $0-10 \mathrm{~cm}$ layer. Soil water content is highest during the early part of the warm season (April/May) and it declines until it reaches a minimum in August. There is general agreement between the in situ observations and CMIP5 ensemble with regards to the seasonal pattern of soil moisture; however, there are notable differences in the magnitude of the soil water content. In addition, the dry-down shown in the CMIP5 ensemble is less pronounced than in the in situ observations. There are substantial intermodel variations among the CMIP5 models, particularly with regards to the absolute soil water content. Similar results are found for the $0-10 \mathrm{~cm}$ soil layer. We will focus on evaluating the performance of individual models in the following sections of the paper.

We also compared the spatial pattern of the mean soil moisture (2003-2012) during the warm season (AprilSeptember; Fig. 4). Based on the CMIP5 ensemble, the soils with the lowest soil water content in the $0-10 \mathrm{~cm}$ layer are typically found in the southwestern US and the soils with the highest soil water content tend to be found in the northeastern US (Fig. 4a). This pattern is also evident in the $0-100 \mathrm{~cm}$ soil layer; however, the gradient is less pronounced (Fig. 4b). The patterns are somewhat less spatially consistent when one examines the in situ observations because of the influence of local factors (e.g., edaphic, climatic, topographic, vegetation).
The differences between CMIP5 and the in situ observations are shown in Fig. 4e and f. Generally, CMIP5 tends to be significantly wetter than the in situ observations in the western US and it tends to be significantly drier than the in situ observations in the eastern US. In fact, $79.3 \%$ of the differences between CMIP5 and the in situ observations in the $0-10 \mathrm{~cm}$ layer are statistically significant. The same patterns are evident in the differences between CMIP5 and the in situ observations in the $0-100 \mathrm{~cm}$ layer (Fig. 4f). However, a greater number ( $8.8 \%$ more) of the positive biases in the western US and the negative biases in the eastern US are statistically significant than in the $0-10 \mathrm{~cm}$ layer. These results agree with previous research. Sheffield et al. (2013) concluded that the CMIP5 models tend to overestimate precipitation in western North America. Given that precipitation is a principal control of soil moisture, a positive bias in precipitation can cause soils to be too wet. Sheffield et al. (2013) also found that CMIP5 models tend to overestimate evaporation in eastern North America. This would lead to drier soils and could help to explain the dry biases in CMIP5 that were observed in the eastern US.

Figure 5 compares the mean warm season (AprilSeptember) soil moisture (2003-2012) in 0-10 cm soil layer from the CMIP5 ensemble to the satellite-derived ECV soil moisture. ECV soil moisture is a product based on remote sensing observations that are rescaled using the Noah land surface model (Noah LSM) from Global Land Date Assimilation System (GLDAS). Although the spatial pattern of ECV soil moisture is influenced by the Noah LSM simulation, it is independent of the GCMs evaluated in this study and therefore can be used to evaluate model performance. The general spatial pattern of ECV is consistent with CMIP5; however, ECV has greater spatial heterogeneity. This is partly due to the finer spatial resolution of the ECV data as compared to CMIP5. It is also apparent that there are signif- 

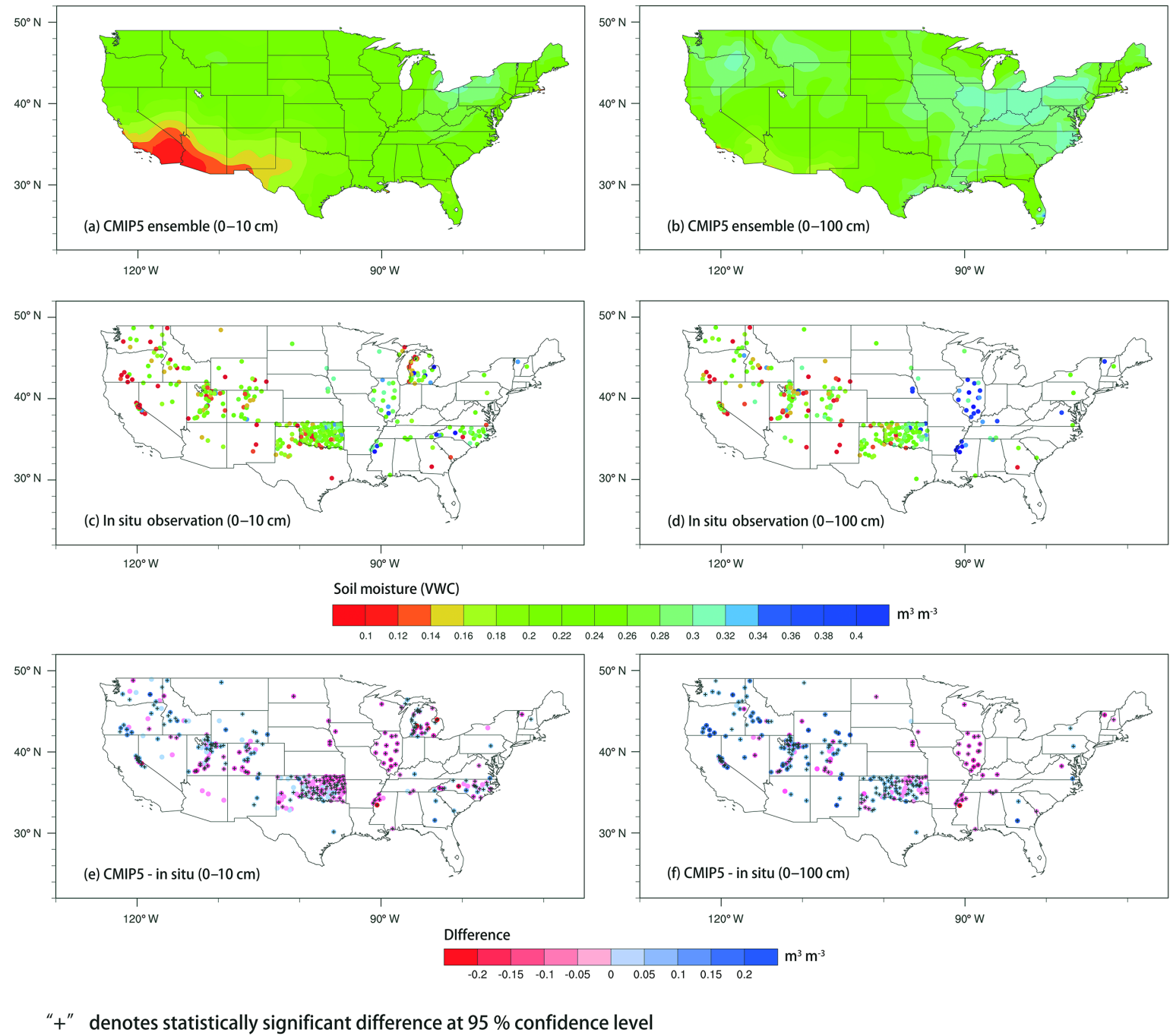

Figure 4. Mean soil moisture $\left(\mathrm{m}^{3} \mathrm{~m}^{-3}\right)$ over CONUS (2003-2012) during the warm season (April to September). Left panels show the 0-10 cm soil moisture for (a) CMIP5 ensemble, (c) in situ observations and (e) the difference between them (CMIP5 - in situ). Right panels show the $0-100 \mathrm{~cm}$ soil moisture for (b) CMIP5 ensemble, (d) in situ observations and (f) the difference between them (CMIP5 - in situ).

icant differences in the near-surface soil water content in ECV versus CMIP5. For example, ECV shows that the regions with relatively low soil water content during the warm season $(\mathrm{VWC}<0.2)$ are much more spatially extensive than in CMIP5. Similarly, the areas with relatively high soil water content (VWC $>0.3$ ) are also more extensive with ECV. There has also been a shift in the soil water maxima in ECV into Maine and New Hampshire, with secondary maxima in Washington. The spatial patterns of the differences between ECV and CMIP5 are similar to those seen with the in situ observations. CMIP5 tends to have wet biases in the western US and dry biases in the eastern US. The majority of statistically significant $(p<0.05)$ differences are concentrated in the places where CMIP5 is wetter than ECV.

\subsection{Evaluation of individual models over CONUS}

We evaluate the performance of each CMIP5 model over CONUS during the warm season using Taylor's skill score, as shown in Fig. 6. Based on the skill score, the individual models show a varying ability to capture the soil moisture distribution over CONUS. In the $0-10 \mathrm{~cm}$ soil layer, CCSM4, NorESM1-M, CESM1 and GFDL-ESM2M all perform well (when compared to in situ observations) and have higher skill scores $(S=0.89,0.87,0.87$ and 0.85$)$ than the CMIP5 ensemble $(S=0.84)$. CanESM2 $(S=0.39)$, INMCM4 $(S=0.47)$ and HadGEM2-ES $(S=0.46)$ have the lowest scores.

When model performance is evaluated using ECV soil moisture, the skill scores decrease for all the models. Among the 17 CMIP5 models that were evaluated, 8 have 

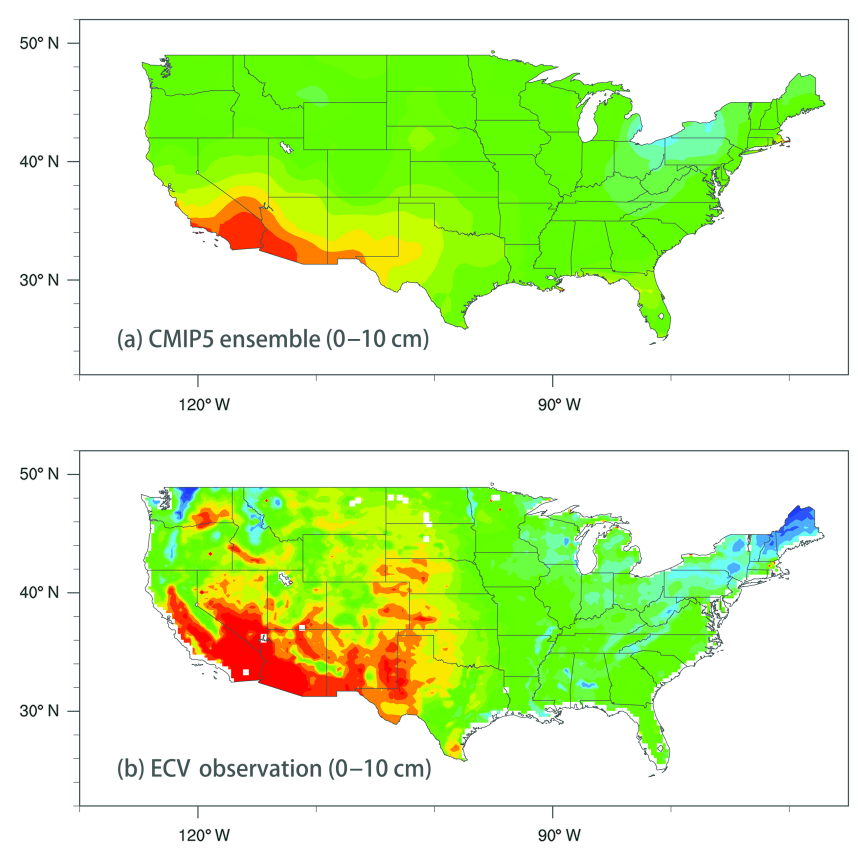

Soil moisture (VWC)

$m^{3} m^{-3}$
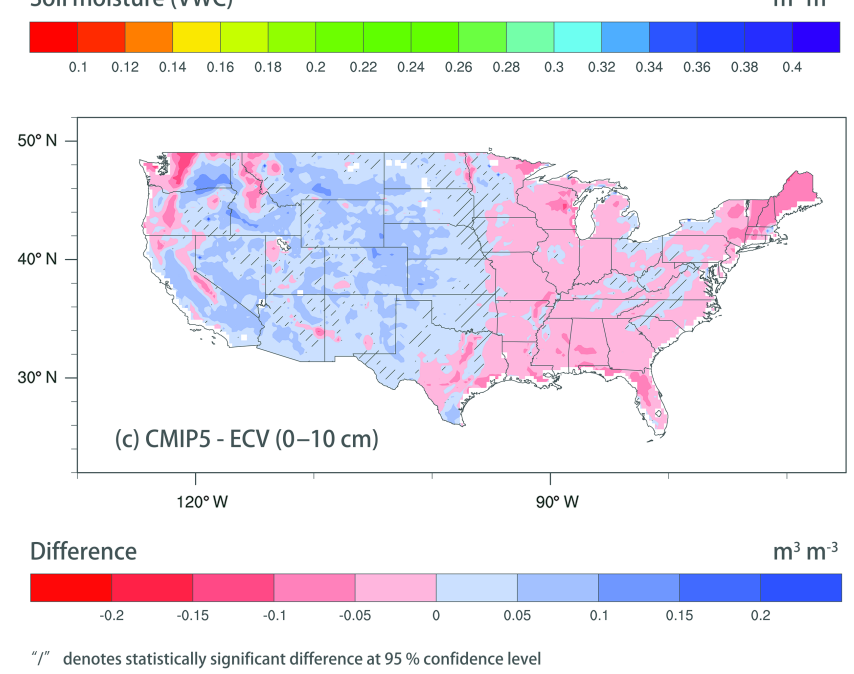

Figure 5. Same as Fig. 4, except it compares the mean soil moisture $\left(\mathrm{m}^{3} \mathrm{~m}^{-3}\right)$ over CONUS (2003-2012) during the warm season (April to September) from the CMIP5 ensemble with the satellitederived ECV soil moisture.

higher skill scores than the CMIP5 ensemble mean (BCCCSM1.1, CCSM4, CESM1, FGOALS-g2, GFDL-ESM2M, GISS-E2-H, IPSL-CM5A-LR and MIROC-ESM). In the 0$100 \mathrm{~cm}$ soil layer, CCSM4 $(S=0.86)$, CESM1 $(S=0.88)$, GFDL-ESM2M $(S=0.80)$ and HadGEM2-ES $(S=0.89)$ perform well. The performance of CanESM2, INM-CM4 and HadGEM2-ES improves in this layer as compared to the $0-10 \mathrm{~cm}$ layer. Generally, CCSM4, CESM1 and GFDLESM2M consistently perform well over CONUS in both the near-surface and deeper soil layers.
The performance of each CMIP5 model is also evaluated using correlation, RMSE and "amplitude of variations" (relative standard deviation). These metrics are represented in Fig. 7 using a Taylor diagram (Taylor, 2001). Correlations between soil moisture simulated by CMIP5 models and ECV and in situ observations are indicated by the azimuthal position of each dot in Fig. 7. Correlations $(r)$ between simulated $0-10 \mathrm{~cm}$ soil moisture and ECV observations (Fig. 7a) are all lower than 0.7. They tend to be clustered around 0.6, with the exception of BNU-ESM. Correlations between the CMIP5 models and the in situ soil moisture observations are more variable, as shown in Fig. 7b. CCSM4 and CESM1 $(r=0.79)$ have the highest correlations, while IPSL-CM5ALR $(r=0.55)$ and GISS-E2-H $(r=0.56)$ have the lowest correlations. The radial distance from the origin represents the standardized deviation of the CMIP5 models relative to the standardized deviation of the observations. When examining the performance of the CMIP5 models in the 0-10 cm soil layer, CanESM2, INM-CM4 and HadGEM2-ES are outliers showing much larger $\left(\sigma_{\mathrm{sim}} / \sigma_{\mathrm{obs}}>2\right)$ variations than either ECV or in situ observations. This leads to low Taylor skill scores for these three models. All the models show larger variations than ECV soil moisture, while only 10 (out of 17) models demonstrate larger variations than in situ soil moisture. In the $0-100 \mathrm{~cm}$ soil layer, the models in Fig. 7c are more clustered than in the $0-10 \mathrm{~cm}$ soil layer. In general, the models tend to underestimate the variability in the $0-100 \mathrm{~cm}$ layer. A total of 12 of the 14 models have standardized deviations that are lower than the observations. This indicates that most of the models cannot capture the true variability of soil moisture in this layer. INM-CM4 significantly overestimates the standardized deviation, which is consistent with the results for the $0-10 \mathrm{~cm}$ soil layer. FGOALS-g2 $(S=0.56)$ has the lowest Taylor skill score in the $0-100 \mathrm{~cm}$ layer. This is due to the low correlation $(r=0.69)$, and the model also significantly underestimates soil moisture variability $\left(\sigma_{\mathrm{sim}} / \sigma_{\mathrm{obs}}=0.51\right)$.

There are many factors that influence the accuracy of soil moisture in ESMs. This includes the quality of the forcing data, the land-atmosphere coupling algorithms, the structure and parameters of the land surface scheme, the representation of physical processes, the spatial resolution of the model, etc. Therefore, it is challenging to identify why certain models are able to simulate soil moisture more accurately than others. Generally, the land surface model used by each ESM plays a critical role in simulating soil moisture. CESM1, CCSM4 and GFDL-ESM2M (which all performed better based on Taylor's skill score) divide the 0$1 \mathrm{~m}$ soil column into 7,7 and 10 layers, respectively. These models provide more detailed soil moisture simulations than CanESM2 and HadGEM2-ES (two layers in 0-1 m soil layer; both performed poorly based on Taylor's skill score). Additionally, the spatial resolutions of CMIP5 models also differ. ESMs with a coarser spatial resolution may also have lower skill because they cannot capture for the spatial variability of 


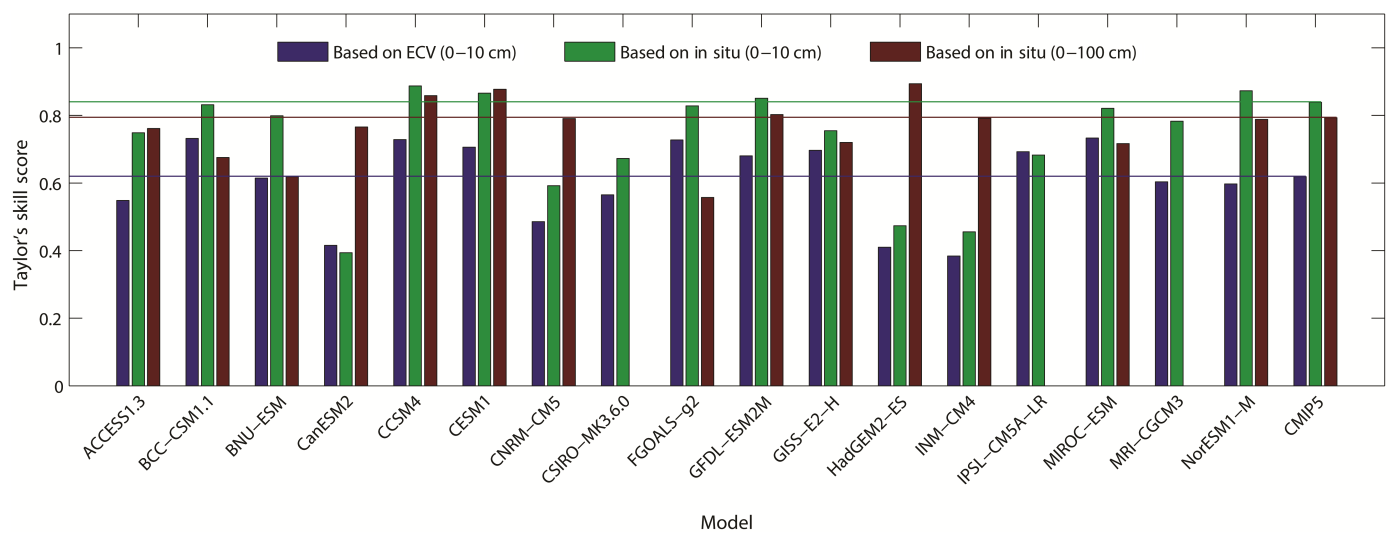

Figure 6. Taylor skill scores of CMIP5 over CONUS based on the ECV satellite data (blue) and in situ observations in the $0-10 \mathrm{~cm}$ soil layer (green) and in 0-100 cm soil moisture (brown). The solid lines indicate the skill of the CMIP5 ensemble average.
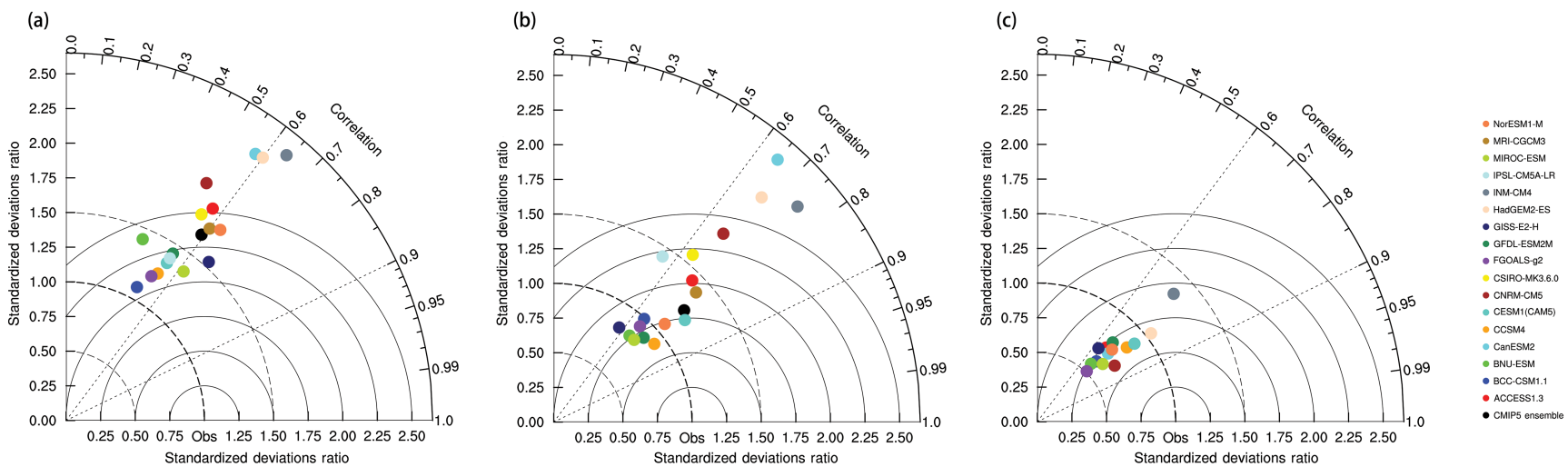

Figure 7. Taylor diagrams for the CMIP5 models based on the (a) ECV satellite data, (b) in situ observations in the 0-10 cm layer and (c) in situ observations in the $0-100 \mathrm{~cm}$ layer. The azimuthal angle represents the correlation coefficient, and radial distance is the standard deviation normalized to observations.

soil moisture. Relative to CESM1 and CCSM4 $(192 \times 288)$, CanESM2 has much coarser spatial resolution $(64 \times 128)$ and a much lower skill score.

\subsection{Regional evaluation}

The CMIP5 models are also evaluated in eight subregions in CONUS (Fig. 8). Correlations between model-simulated and in situ surface soil moisture (green bar) are higher in all subregions than the correlations (blue bar) based on ECV soil moisture, except in the NGP region (Fig. 8a). Focusing on the correlations between CMIP5 ensemble and in situ soil moisture, correlations for $0-100 \mathrm{~cm}$ soil moisture (brown bar) are similar to the correlations for $0-10 \mathrm{~cm}$ soil moisture. Only in the NGP region, correlation in $0-100 \mathrm{~cm}$ soil layer is substantially higher than in $0-10 \mathrm{~cm}$ soil layer. Examining the MAE gives a different perspective. In most subregions, the CMIP5 ensemble has a lower MAE when compared to ECV versus the in situ observations. Only in the Northern Shrubland and Southern Shrubland regions, the MAE is lower when compared to the in situ observations. Figure $8 \mathrm{~b}$ indicates that
MAE in the $0-100 \mathrm{~cm}$ soil layer is substantially higher than MAE in $0-10 \mathrm{~cm}$ soil layer in seven of the eight subregions. Similarly, the coefficient of efficiency is generally higher in the $0-10 \mathrm{~cm}$ layer than in $0-100 \mathrm{~cm}$.

Model performance varies from subregion to subregion. Based on the ECV soil moisture, the CMIP5 ensemble has relatively high correlations $(r=0.64$ and 0.66$)$ in the MW and NE and relatively low correlations $(r=0.23)$ in the SS region. Based on the in situ soil moisture, correlations are consistently high $(r>0.85)$ in NS, NW, SE, SGP and SS in both the near-surface and deep soil layers. The lowest correlation $(r=0.50)$ between the nearsurface in situ soil moisture and CMIP5 ensemble is in the NGP. The MAE based on ECV soil moisture is relatively low in the NE, NGP and NW (MAE $=0.021,0.021$ and $0.021 \mathrm{~cm}^{3} \mathrm{~cm}^{-3}$ ) and relatively high in NS and SS (MAE $=0.042$ and $0.046 \mathrm{~cm}^{3} \mathrm{~cm}^{-3}$ ). However, when compared to the near-surface in situ soil moisture, MAE is relatively high in the NW $\left(\mathrm{MAE}=0.037 \mathrm{~cm}^{3} \mathrm{~cm}^{-3}\right)$. 

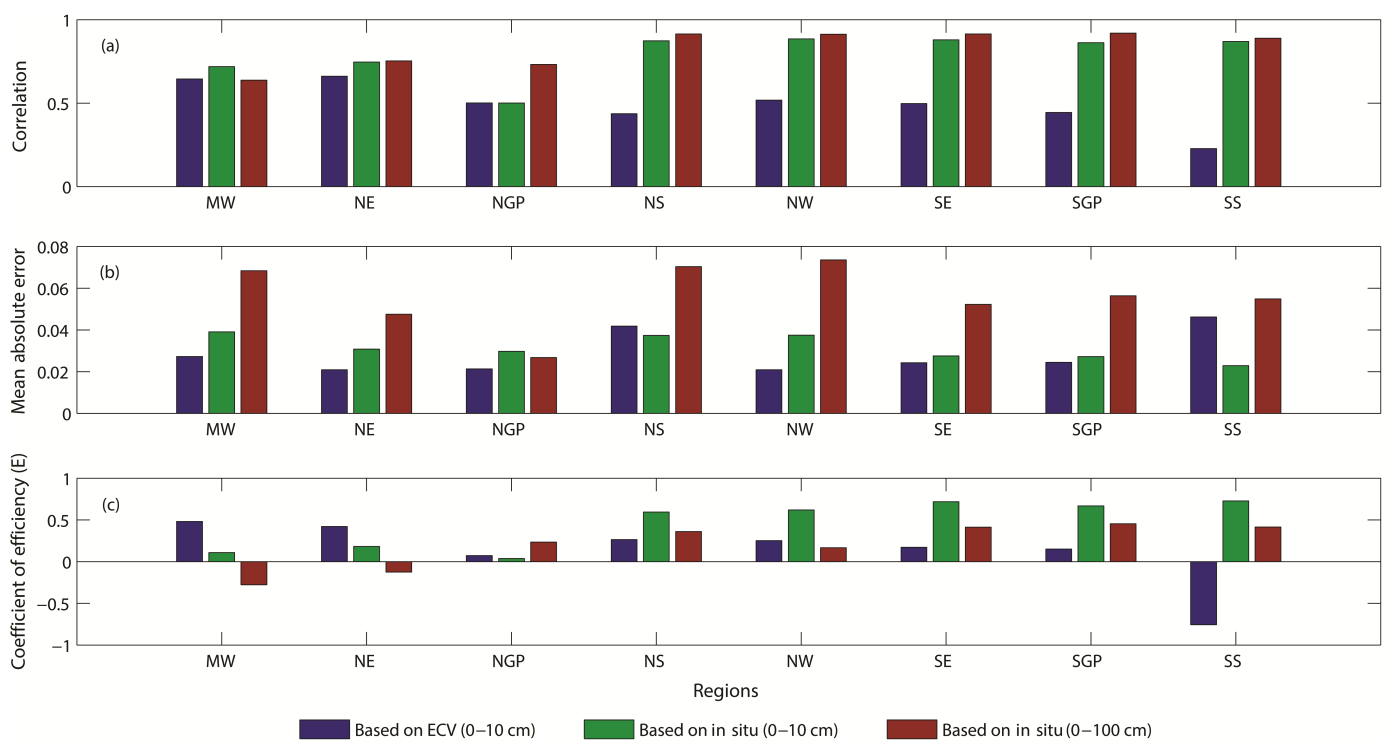

Figure 8. Performance evaluation statistics for CMIP5 ensemble mean versus ECV satellite data and in situ soil moisture (2003-2012): (a) correlation coefficient, (b) mean absolute error and (c) coefficient of efficiency for the eight subregions.

There is substantially more regional variability in MAE for the $0-100 \mathrm{~cm}$ soil moisture. The MAE exceeds $0.07 \mathrm{~cm}^{3} \mathrm{~cm}^{-3}$ in NS and NW, while in the NGP it is only $0.03 \mathrm{~cm}^{3} \mathrm{~cm}^{-3}$. The regional variation in coefficient of efficiency $(E)$ is also substantial. When $E$ is calculated based on the in situ observations, it demonstrates that the CMIP5 ensemble can skillfully simulate the $0-10 \mathrm{~cm}$ soil moisture in the NS, NW, SE, SGP and SS regions. The results also demonstrate that CMIP5 can accurately simulate the 0 $100 \mathrm{~cm}$ soil moisture in the NS, SE, SGP and SS regions during the warm season. However, these results do not agree with the performance assessment based on the ECV soil moisture. Based on ECV, $E$ is best in the MW and NE regions and CMIP5 model ensemble is worse than climatology in the SS region.

Based on the results presented above, model performance differs significantly when being evaluated with in situ versus ECV soil moisture. In addition, the selection of the bestperforming models is dependent on which statistic is used. For example, based on the in situ soil moisture in $0-10 \mathrm{~cm}$ layer, the NS and NW regions have relatively high MAE $\left(\mathrm{MAE}=0.037\right.$ and $0.037 \mathrm{~cm}^{3} \mathrm{~cm}^{-3}$ ) even though the correlations are also strong $(r=0.87$ and 0.89$)$. This suggests that the model is able to simulate the wetting and drying of the soil, but there is a systematic bias in the absolute magnitude of the model-simulated soil moisture.

Figure 9 shows the skill scores of each model in the eight subregions using in situ observations from the warm season as reference. There is substantial intermodel variability in performance amongst the CMIP5 models as a function of soil depth and location. CESM1 has consistently high skill in the $0-10 \mathrm{~cm}$ soil layer in all eight subregions. MRI-CGCM3 out- performs all the other models in the MW region and it also performs well in the NE along with ACCESS1.3. CanESM2 and HadGEM2-ES do not perform well in the majority of subregions (six out of eight subregions) and GISS-E2-H does not perform well in the MW and NE. For the $0-100 \mathrm{~cm}$ soil layer, HadGEM2-ES performs well in all subregions, especially in NGP, NS, NW, SE and SGP. The models generally perform better in the NE, compared to other subregions. FGOALS-g2 and GISS-E2-H perform relatively poorly in all subregions.

Due to the availability of ECV data and the issues with measuring soil moisture in frozen soils, the preceding analysis focused solely on the warm season. We also evaluated model performance using data from all months in the three southern subregions (SE, SGP and SS) where frozen soils are not an issue. Figure 10 shows the seasonal cycle of soil moisture based on the CMIP5 ensemble, in situ and ECV data in the three southern subregions. CMIP5 ensembles in the three subregions consistently show that soil moisture decreases first and then increases in a year. However, in SE, soil moisture reaches the driest condition (in September) later than soil moisture in SGP (August) and SS (July). Both the in situ and ECV show more variable seasonal patterns than the CMIP5 simulations, especially in the SGP and SS. In the SE, both the in situ and ECV soil moisture decrease starting in February and reach their lowest point in June. This is 3 months earlier than the CMIP5 ensemble. In situ observations are wetter than ECV soil moisture during the entire year in the SE, but they are most similar in October. In the SGP, in situ and ECV soil moisture generally decreases from April to August and then increases after August. There is good agreement between the in situ, ECV and CMIP5 in the SGP with 

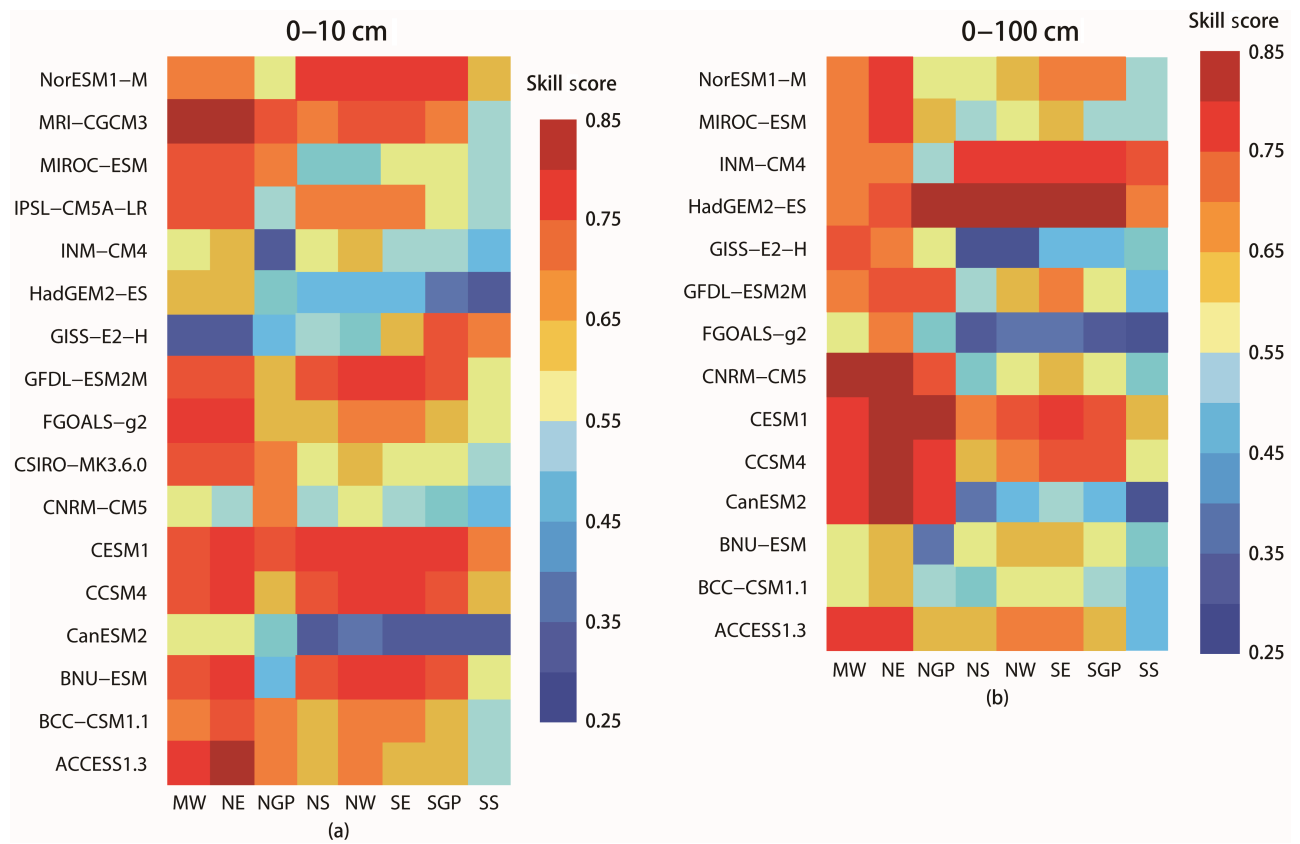

Figure 9. Comparison of CMIP5 models with in situ observations over eight subregions based on Taylor skill scores: (a) 0-10 cm soil moisture and (b) $0-100 \mathrm{~cm}$ soil moisture.
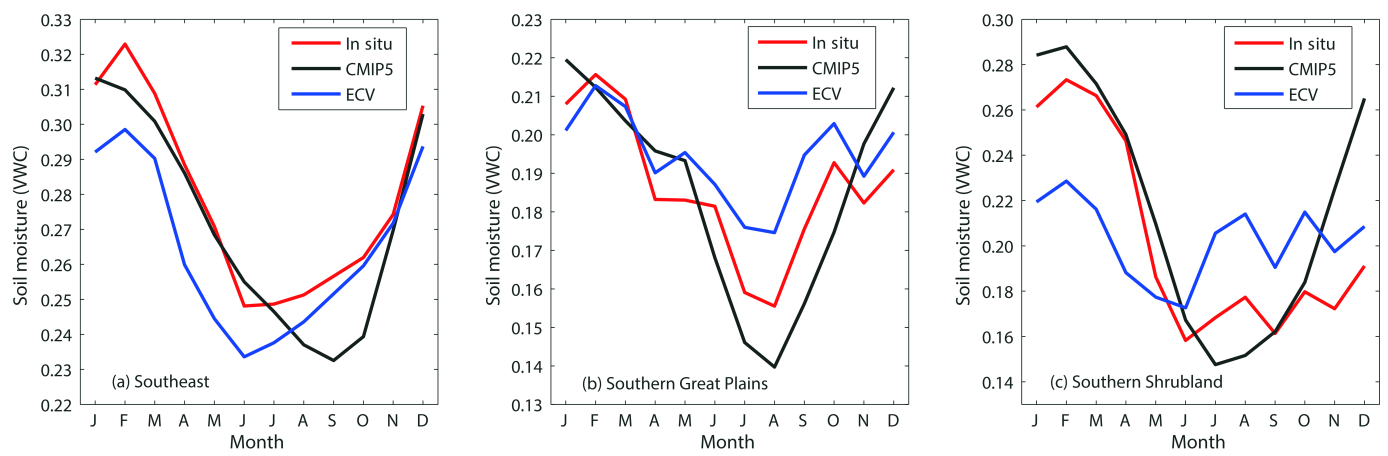

Figure 10. Seasonal variation of mean monthly (2003-2012) soil moisture based on in situ observations (red), CMIP5 ensemble (black) and ECV satellite data (blue) in three subregions: (a) Southeast, (b) Southern Great Plains and (c) Southern Shrubland.

regards to the timing of the wettest and driest months. This is the only subregion where the seasonal cycle is the same in all three data sources. However, the magnitude of the seasonal fluctuations differs substantially. CMIP5 is much more variable than both the in situ and ECV. While in the SS region, the ECV does not show much of a seasonal cycle. CMIP5 and the in situ observations show a similar drying of the soil from March through June, but they do not agree as well during the June to November period. Table 3 provides the correlation, MAE and $E$ based on the monthly data from these three subregions. During the warm season months, the correlations and coefficient of efficiency are higher and the MAE is lower in all the cases. In terms of the surface layer, the CMIP5 ensemble is more highly correlated with in situ observations than ECV data in all three subregions. However, in the SGP and SE, the MAE based on comparing the CMIP5 ensemble to the ECV is lower than the MAE based on the in situ observations. With emphasis on in situ soil moisture in different layers, CMIP5 ensemble has higher correlation, larger MAE and lower $E$ in $0-100 \mathrm{~cm}$ soil layer than in 0 $10 \mathrm{~cm}$ soil layer in all the three subregions.

\section{Limitations}

This study compares model-simulated soil moisture from the CMIP5 models with in situ and satellite-derived soil moisture. The in situ stations were selected based on their record length spatial coverage. However, there are relatively few stations with 10-year records. Therefore, some parts of CONUS are not well represented in this analysis. Future studies would 
Table 3. Evaluation of CMIP5 ensemble over the Southeast, Southern Great Plains and Southern Shrubland using all monthly soil moisture and warm-season-only soil moisture.

\begin{tabular}{llcc|rc|rrr}
\hline & & \multicolumn{2}{c}{ Correlation } & \multicolumn{2}{c|}{ MAE } & \multicolumn{2}{c}{$E$} \\
\cline { 3 - 8 } & & All & Warm & All & Warm & All & Warm \\
\hline \multirow{2}{*}{ SE } & vs. ECV & 0.44 & 0.50 & 0.030 & 0.024 & 0.11 & 0.17 \\
& vs. in situ $(0-10 \mathrm{~cm})$ & 0.80 & 0.88 & 0.032 & 0.028 & 0.61 & 0.72 \\
& vs. in situ $(0-100 \mathrm{~cm})$ & 0.89 & 0.91 & 0.067 & 0.052 & 0.21 & 0.43 \\
\hline \multirow{2}{*}{ SGP } & vs. ECV & 0.38 & 0.44 & 0.026 & 0.024 & 0.05 & 0.15 \\
& vs. in situ $(0-10 \mathrm{~cm})$ & 0.82 & 0.86 & 0.032 & 0.027 & 0.63 & 0.67 \\
& vs. in situ $(0-100 \mathrm{~cm})$ & 0.90 & 0.92 & 0.071 & 0.056 & 0.19 & 0.45 \\
\hline \multirow{2}{*}{ SS } & vs. ECV & 0.21 & 0.23 & 0.051 & 0.046 & -1.12 & -0.76 \\
& vs. in situ $(0-10 \mathrm{~cm})$ & 0.81 & 0.87 & 0.028 & 0.023 & 0.66 & 0.73 \\
& vs. in situ $(0-100 \mathrm{~cm})$ & 0.88 & 0.89 & 0.074 & 0.055 & 0.17 & 0.41 \\
\hline
\end{tabular}

benefit from including more in situ data to evaluate model performance. This would help to address issues with the spatial gaps in coverage and the issues related to comparing point measurements to model grid cells. Considering the in situ soil moisture comes from different networks, there may also be some inconsistencies in the quality and representativeness of the soil moisture data (Dirmeyer et al., 2016). These inconsistencies can result from the use of different soil moisture sensors, calibration procedures and quality control processes. Dirmeyer et al. (2016) assessed the random errors of 16 networks and found distinct differences between networks. Although we excluded from this study one of the networks with the largest random errors (e.g., COSMOS), more work is still needed to standardize and homogenize in situ soil moisture measurements.

Another potential limitation of this work is that we applied bilinear interpolation method to regrid all the CMIP5 model output to a uniform resolution of $0.25^{\circ} \times 0.25^{\circ}$ so that it matched the resolution of the ECV data. This is a simple way of rescaling the data. Given that we are only evaluating model performance at the regional and continental scales, we believe that this method is reasonable because the spatial variability of soil moisture at these scales is dominated by precipitation patterns (Crow et al., 2012). However, applying more advanced interpolation or downscaling methods, such as the reduced optimal interpolation (ROI) method (Yuan and Quiring, 2016), may provide a better estimate of model-simulated soil moisture at this spatial scale.

\section{Conclusions}

We evaluated soil moisture simulations in CMIP5 experiment (17 models for $0-10 \mathrm{~cm}$ and 14 models for $0-100 \mathrm{~cm}$ ) over CONUS using in situ observations and ECV satellite observations. The CONUS results show that the CMIP5 model ensemble has similar correlations with in situ observations when comparing the $0-100 \mathrm{~cm}$ soil layer to the $0-10 \mathrm{~cm}$ soil layer. However, there is evidence of a substantial wet bias in the deeper soil layer during months when the soil is dry. This wet bias is also reflected in the multiyear mean monthly soil moisture. There is substantial variability in performance among the individual models, with the greater uncertainties in surface soil layer.

The multimodel CMIP5 ensemble mean can generally capture the spatial pattern of soil moisture. However, wet biases in the western US and dry biases in the eastern US are evident. Sheffield et al. (2013) found that CMIP5 models tend to overestimate precipitation in the western US, and this may account for the wet biases that we observed. Dry biases in the eastern US may be attributed to evapotranspiration, which tends to be overestimated by CMIP5 models in the eastern US (Sheffield et al., 2013). Performance of the CMIP5 ensemble varies significantly from subregion to subregion. In most subregions (NS, NW, SE, SGP and SS), the CMIP5 ensemble can accurately simulate warm season surface soil moisture (e.g., high correlations and low MAE). In the three southern subregions, we also evaluated soil moisture simulations during the cold season and found that there is generally a decrease in model performance (e.g., higher MAE and lower $E$ than during the warm season).

ECV soil moisture, as an independent data source, is introduced in this study to help evaluate the performance of CMIP5 soil moisture simulations. Relative to ECV soil moisture, CMIP5 ensemble shows greater month-to-month variations over CONUS. Due to this greater variance, CMIP5 models do not skillfully reproduce the ECV soil moisture. Similar to in situ soil moisture, ECV data also show that the CMIP5 model ensemble tends to have wet biases in the western US and dry biases in the eastern US. Additionally, in the three southern subregions, the intra-annual variability shown by ECV soil moisture and in situ observations is relatively consistent. On the other hand, the CMIP5 ensemble can only capture the general seasonal cycle, but fails to adequately capture some of the monthly variations. At the 
same time, there are some inconsistencies between the in situ and ECV soil moisture. For example, in the Southern Shrubland, the correlation between the CMIP5 models and ECV soil moisture $(r=0.23)$ is lower than the correlation with the in situ data $(r=0.87)$. Though comparing the two observational data is not the goal of this study, we can still point out that future validation of satellite-derived soil moisture is necessary.

The skill of the individual CMIP5 models also varies significantly. In the top soil layer, the Taylor skill score varies from 0.39 (CanESM2) to 0.89 (CCSM4). Generally, the skill of the models in the deeper soil layer is similar to the surface layer, but the intermodel variability in skill is greater. HadGEM2-ES has the highest skill score because it matches the variability of the in situ observations. Generally, CESM1 consistently performs well in the surface soil layer in all subregions, and HadGEM2-ES performs well in the $0-100 \mathrm{~cm}$ soil layers in all subregions. However, it is remains difficult to find a single model that consistently outperforms all others when it comes to accurately simulating soil moisture in all subregions and seasons. Therefore, it is unclear whether the findings of this study will apply to other subregions around the world with different climate, soil and vegetation characteristics.

Data availability. The in situ soil moisture dataset is available at TAMU North American Soil Moisture Database (http: //soilmoisture.tamu.edu/). The satellite-observed soil moisture is available at the European Space Agency soil moisture climate change initiative (CCI) project website (http://www. esa-soilmoisture-cci.org/). CMIP5-simulated soil moisture is provided by the Earth System Grid Federation (ESGF; https://pcmdi9. llnl.gov/).

Competing interests. The authors declare that they have no conflict of interest.

Acknowledgements. This work was supported by NSF grant AGS-1056796 to Texas A\&M University.

Edited by: S. Attinger

Reviewed by: R. Orth and one anonymous referee

\section{References}

Albergel, C., de Rosnay, P., Balsamo, G., Isaksen, L., and MuñozSabater, J.: Soil Moisture Analyses at ECMWF: Evaluation Using Global Ground-Based In Situ Observations, J. Hydrometeorol., 13, 1442-1460, doi:10.1175/JHM-D-11-0107.1, 2012a.

Albergel, C., de Rosnay, P., Gruhier, C., Muñoz-Sabater, J., Hasenauer, S., Isaksen, L., Kerr, Y., and Wagner, W.: Evaluation of remotely sensed and modelled soil moisture products using global ground-based in situ observations, Remote Sens. Environ., 118 , 215-226, doi:10.1016/j.rse.2011.11.017, 2012b.

Albergel, C., Dorigo, W., Balsamo, G., Muñoz-Sabater, J., de Rosnay, P., Isaksen, L., Brocca, L., de Jeu, R., and Wagner, W.: Monitoring multi-decadal satellite earth observation of soil moisture products through land surface reanalyses, Remote Sens. Environ., 138, 77-89, doi:10.1016/j.rse.2013.07.009, 2013a.

Albergel, C., Dorigo, W., Reichle, R. H., Balsamo, G., de Rosnay, P., Muñoz-Sabater, J., Isaksen, L., de Jeu, R., and Wagner, W.: Skill and Global Trend Analysis of Soil Moisture from Reanalyses and Microwave Remote Sensing, J. Hydrometeorol., 14, 1259-1277, doi:10.1175/JHM-D-12-0161.1, 2013 b.

An, R., Zhang, L., Wang, Z., Quaye-Ballard, J. A., You, J., Shen, X., Gao, W., Huang, L., Zhao, Y., and Ke, Z.: Validation of the ESA CCI soil moisture product in China, Int. J. Appl. Earth Obs., 48, 28-36, doi:10.1016/j.jag.2015.09.009, 2016.

Andresen, J., Olse, L., Aichele, T., Bishop, B., Brown, J., Landis, J., Marquie, S., and Pollyea, A.: Enviro-weather: A weatherbased pest and crop management information system for Michigan, Seventh Int. Integrated Pest Management Symp, Memphis, TN, 2011.

Baldocchi, D., Falge, E., Gu, L., Olson, R., Hollinger, D., Running, S., Anthoni, P., Bernhofer, C., Davis, K., Evans, R., Fuentes, J., Goldstein, A., Katul, G., Law, B., Lee, X., Malhi, Y., Meyers, T., Munger, W., Oechel, W., Paw, K. T., Pilegaard, K., Schmid, H. P., Valentini, R., Verma, S., Vesala, T., Wilson, K., and Wofsy, S.: FLUXNET: A New Tool to Study the Temporal and Spatial Variability of EcosystemScale Carbon Dioxide, Water Vapor, and Energy Flux Densities, B. Am. Meteorol. Soc., 82, 2415-2434, doi:10.1175/15200477(2001)082<2415:FANTTS>2.3.CO;2, 2001.

Bindoff, N. L., Stott, P. A., AchutaRao, K. M., Allen, M. R., Gillett, N., Gutzler, D., Hansingo, K., Hegerl, G., Hu, Y., Jain, S., Mokhov, I. I., Overland, J., Perlwitz, J., Sebbari, R., and Zhang, $\mathrm{X}$.: Detection and Attribution of Climate Change: from Global to Regional, in: Climate Change 2013: The Physical Science Basis. Contribution of Working Group I to the Fifth Assessment Report of the Intergovernmental Panel on Climate Change, Cambridge, United Kingdom and New York, NY, USA, 2013.

Brocca, L., Hasenauer, S., Lacava, T., Melone, F., Moramarco, T., Wagner, W., Dorigo, W., Matgen, P., Martínez-Fernández, J., Llorens, P., Latron, J., Martin, C., and Bittelli, M.: Soil moisture estimation through ASCAT and AMSR-E sensors: An intercomparison and validation study across Europe, Remote Sens. Environ., 115, 3390-3408, doi:10.1016/j.rse.2011.08.003, 2011.

Brocca, L., Moramarco, T., Melone, F., and Wagner, W.: A new method for rainfall estimation through soil moisture observations, Geophys. Res. Lett., 40, 853-858, doi:10.1002/grl.50173, 2013.

Brown, M. E., Escobar, V., Moran, S., Entekhabi, D., O’Neill, P. E., Njoku, E. G., Doorn, B., and Entin, J. K.: NASA's Soil Moisture Active Passive (SMAP) Mission and Opportunities for Applications Users, B. Am. Meteorol. Soc., 94, 1125-1128, doi:10.1175/BAMS-D-11-00049.1, 2013.

Chen, L. and Frauenfeld, O. W.: A comprehensive evaluation of precipitation simulations over China based on CMIP5 multimodel ensemble projections, J. Geophys. Res.-Atmos., 119 , 5767-5786, doi:10.1002/2013JD021190, 2014 
Crow, W. T., Berg, A. A., Cosh, M. H., Loew, A., Mohanty, B. P., Panciera, R., de Rosnay, P., Ryu, D., and Walker, J. P.: Upscaling sparse ground-based soil moisture observations for the validation of coarse-resolution satellite soil moisture products, Rev. Geophys., 50, RG2002, 10.1029/2011RG000372, 2012.

Detto, M., Montaldo, N., Albertson, J. D., Mancini, M., and Katul, G.: Soil moisture and vegetation controls on evapotranspiration in a heterogeneous Mediterranean ecosystem on Sardinia, Italy, Water Resour. Res., 42, n/a-n/a, 10.1029/2005WR004693, 2006.

Dirmeyer, P. A., Jin, Y., Singh, B., and Yan, X.: Trends in LandAtmosphere Interactions from CMIP5 Simulations, J. Hydrometeorol., 14, 829-849, doi:10.1175/JHM-D-12-0107.1, 2013.

Dirmeyer, P. A., Wu, J., Norton, H. E., Dorigo, W. A., Quiring, S. M., Ford, T. W., Santanello, J. A., Bosilovich, M. G., Ek, M. B., Koster, R. D., Balsamo, G., and Lawrence, D. M.: Confronting Weather and Climate Models with Observational Data from Soil Moisture Networks over the United States, J. Hydrometeorol., 17, 1049-1067, doi:10.1175/JHM-D-15-0196.1, 2016.

Dorigo, W. A., Wagner, W., Hohensinn, R., Hahn, S., Paulik, C., Xaver, A., Gruber, A., Drusch, M., Mecklenburg, S., van Oevelen, P., Robock, A., and Jackson, T.: The International Soil Moisture Network: a data hosting facility for global in situ soil moisture measurements, Hydrol. Earth Syst. Sci., 15, 1675-1698, doi:10.5194/hess-15-1675-2011, 2011.

Dorigo, W. A., Gruber, A., De Jeu, R. A. M., Wagner, W., Stacke, T., Loew, A., Albergel, C., Brocca, L., Chung, D., Parinussa, R. M., and Kidd, R.: Evaluation of the ESA CCI soil moisture product using ground-based observations, Remote Sens. Environ., 162, 380-395, doi:10.1016/j.rse.2014.07.023, 2015.

Ek, M. B. and Holtslag, A. A. M.: Influence of Soil Moisture on Boundary Layer Cloud Development, J. Hydrometeorol., 5, 86-99, doi:10.1175/15257541(2004)005<0086:IOSMOB>2.0.CO;2, 2004.

Fang, L., Hain, C. R., Zhan, X., and Anderson, M. C.: An intercomparison of soil moisture data products from satellite remote sensing and a land surface model, Int. J. Appl. Earth Obs., 48, 37-50, doi:10.1016/j.jag.2015.10.006, 2016.

Ford, T. W. and Quiring, S. M.: In situ soil moisture coupled with extreme temperatures: A study based on the Oklahoma Mesonet, Geophys. Res. Lett., 41, 2014GL060949, 10.1002/2014GL060949, 2014a.

Ford, T. W. and Quiring, S. M.: Comparison and application of multiple methods for temporal interpolation of daily soil moisture, International J. Climatol., 34, 2604-2621, doi:10.1002/joc.3862, 2014b.

Ford, T. W., McRoberts, D. B., Quiring, S. M., and Hall, R. E.: On the utility of in situ soil moisture observations for flash drought early warning in Oklahoma, USA, Geophys. Res. Lett., 42, 9790-9798, doi:10.1002/2015GL066600, 2015a.

Ford, T. W., Quiring, S. M., Frauenfeld, O. W., and Rapp, A. D.: Synoptic conditions related to soil moisture-atmosphere interactions and unorganized convection in Oklahoma, J. Geophys. Res.-Atmos., 120, 11519-11535, doi:10.1002/2015JD023975, $2015 b$.

Ford, T. W., Rapp, A. D., and Quiring, S. M.: Does Afternoon Precipitation Occur Preferentially over Dry or Wet Soils in Oklahoma?, J. Hydrometeorol., 16, 874-888, doi:10.1175/JHM-D14-0005.1, 2015c.
Guo, Z. and Dirmeyer, P. A.: Evaluation of the Second Global Soil Wetness Project soil moisture simulations: 1. Intermodel comparison, J. Geophys. Res.-Atmos., 111, D22S02, doi:10.1029/2006JD007233, 2006.

Hartmann, D. L., Klein Tank, A. M. G., Rusticucci, M., Alexander, L. V., Brönnimann, S., Charabi, Y., Dentener, F. J., Dlugokencky, E. J., Easterling, D. R., Kaplan, A., Soden, B. J., Thorne, P. W., Wild, M., and Zhai, P. M.: Observations: Atmosphere and Surface, in: Climate Change 2013: The Physical Science Basis, Contribution of Working Group I to the Fifth Assessment Report of the Intergovernmental Panel on Climate Change, edited by: Stocker, T. F., Qin, D., Plattner, G.-K., Tignor, M., Allen, S. K., Boschung, J., Nauels, A., Xia, Y., Bex, V., and Midgley, P. M., Cambridge University Press, Cambridge, United Kingdom and New York, NY, USA, 2013.

Hollinger, S. E., Reinke, B. C., and Peppler, R. A.: Illinois Climate Network: Site Descriptions, Instrumentation, and Data Management, Champaign, IL 62, 1994.

Hsu, P.-C., Li, T., Murakami, H., and Kitoh, A.: Future change of the global monsoon revealed from 19 CMIP5 models, J. Geophys. Res.-Atmos., 118, 1247-1260, doi:10.1002/jgrd.50145, 2013.

Jones, G. S., Stott, P. A., and Christidis, N.: Attribution of observed historical near-surface temperature variations to anthropogenic and natural causes using CMIP5 simulations, J. Geophys. Res.Atmos., 118, 4001-4024, doi:10.1002/jgrd.50239, 2013.

Kerr, Y. H., Waldteufel, P., Wigneron, J. P., Martinuzzi, J., Font, J., and Berger, M.: Soil moisture retrieval from space: the Soil Moisture and Ocean Salinity (SMOS) mission, IEEE T. Geosci. Remote, 39, 1729-1735, doi:10.1109/36.942551, 2001.

Koster, R. D., Dirmeyer, P. A., Guo, Z., Bonan, G., Chan, E., Cox, P., Gordon, C. T., Kanae, S., Kowalczyk, E., Lawrence, D., Liu, P., Lu, C.-H., Malyshev, S., McAvaney, B., Mitchell, K., Mocko, D., Oki, T., Oleson, K., Pitman, A., Sud, Y. C., Taylor, C. M., Verseghy, D., Vasic, R., Xue, Y., and Yamada, T.: Regions of Strong Coupling Between Soil Moisture and Precipitation, Science, 305, 1138-1140, doi:10.1126/science.1100217, 2004.

Koster, R. D., Guo, Z., Yang, R., Dirmeyer, P. A., Mitchell, K., and Puma, M. J.: On the Nature of Soil Moisture in Land Surface Models, J. Climate, 22, 4322-4335, doi:10.1175/2009JCLI2832.1, 2009.

Latron, J. and Gallart, F.: Runoff generation processes in a small Mediterranean research catchment (Vallcebre, Eastern Pyrenees), J. Hydrology, 358, 206-220, doi:10.1016/j.jhydrol.2008.06.014, 2008.

Legates, D. R. and McCabe, G. J.: Evaluating the use of "goodness-of-fit" Measures in hydrologic and hydroclimatic model validation, Water Resour. Res., 35, 233-241, doi:10.1029/1998WR900018, 1999.

Le Vine, D. M., Lagerloef, G. S. E., Colomb, F. R., Yueh, S. H., and Pellerano, F. A.: Aquarius: An Instrument to Monitor Sea Surface Salinity From Space, IEEE T. Geosci. Remote, 45, 2040-2050, doi:10.1109/TGRS.2007.898092, 2007.

Li, H., Robock, A., and Wild, M.: Evaluation of Intergovernmental Panel on Climate Change Fourth Assessment soil moisture simulations for the second half of the twentieth century, J. Geophys. Res.-Atmos., 112, D06106, doi:10.1029/2006JD007455, 2007.

Liu, Y. Y., Parinussa, R. M., Dorigo, W. A., De Jeu, R. A. M., Wagner, W., van Dijk, A. I. J. M., McCabe, M. F., and Evans, J. P.: Developing an improved soil moisture dataset by blending passive 
and active microwave satellite-based retrievals, Hydrol. Earth Syst. Sci., 15, 425-436, doi:10.5194/hess-15-425-2011, 2011.

Liu, Y. Y., Dorigo, W. A., Parinussa, R. M., de Jeu, R. A. M., Wagner, W., McCabe, M. F., Evans, J. P., and van Dijk, A. I. J. M.: Trend-preserving blending of passive and active microwave soil moisture retrievals, Remote Sens. Environ., 123, 280-297, doi:10.1016/j.rse.2012.03.014, 2012.

Lorenz, R., Argüeso, D., Donat, M. G., Pitman, A. J., van den Hurk, B., Berg, A., Lawrence, D. M., Chéruy, F., Ducharne, A., Hagemann, S., Meier, A., Milly, P. C. D., and Seneviratne, S. I.: Influence of land-atmosphere feedbacks on temperature and precipitation extremes in the GLACE-CMIP5 ensemble, J. Geophys. Res.-Atmos., 121, 607-623, doi:10.1002/2015JD024053, 2016.

Loveland, T. R., Reed, B. C., Brown, J. F., Ohlen, D. O., Zhu, Z., Yang, L., and Merchant, J. W.: Development of a global land cover characteristics database and IGBP DISCover from $1 \mathrm{~km}$ AVHRR data, Int. J. Remote Sens., 21, 1303-1330, doi:10.1080/014311600210191, 2000.

May, W., Meier, A., Rummukainen, M., Berg, A., Chéruy, F., and Hagemann, S.: Contributions of soil moisture interactions to climate change in the tropics in the GLACE-CMIP5 experiment, Clim. Dynam., 45, 3275-3297, doi:10.1007/s00382-015-2538-9, 2015.

McNally, A., Shukla, S., Arsenault, K. R., Wang, S., PetersLidard, C. D., and Verdin, J. P.: Evaluating ESA CCI soil moisture in East Africa, Int. J. Appl. Earth Obs., 48, 96-109, doi:10.1016/j.jag.2016.01.001, 2016.

Mei, R. and Wang, G.: Summer Land-Atmosphere Coupling Strength in the United States: Comparison among Observations, Reanalysis Data, and Numerical Models, J. Hydrometeorol., 13, 1010-1022, doi:10.1175/JHM-D-11-075.1, 2012.

Notaro, M., Liu, Z., and Williams, J. W.: Observed VegetationClimate Feedbacks in the United States, J. Climate, 19, 763-786, doi:10.1175/JCLI3657.1, 2006.

Pan, W., Boyles, R. P., White, J. G., and Heitman, J. L.: Characterizing Soil Physical Properties for Soil Moisture Monitoring with the North Carolina Environment and Climate Observing Network, J. Atmos. Ocean. Technol., 29, 933-943, doi:10.1175/JTECH-D-11-00104.1, 2012.

Penna, D., Tromp-van Meerveld, H. J., Gobbi, A., Borga, M., and Dalla Fontana, G.: The influence of soil moisture on threshold runoff generation processes in an alpine headwater catchment, Hydrol. Earth Syst. Sci., 15, 689-702, doi:10.5194/hess-15-6892011, 2011.

Pratola, C., Barrett, B., Gruber, A., Kiely, G., and Dwyer, E.: Evaluation of a Global Soil Moisture Product from Finer Spatial Resolution SAR Data and Ground Measurements at Irish Sites, Remote Sensing, 6, 8190-8219, 2014.

Qu, X., Huang, G., and Zhou, W.: Consistent responses of East Asian summer mean rainfall to global warming in CMIP5 simulations, Theor. Appl. Climatol., 117, 123-131, 1doi:0.1007/s00704-013-0995-9, 2013.

Quiring, S. M., Ford, T. W., Wang, J. K., Khong, A., Harris, E., Lindgren, T., Goldberg, D. W., and Li, Z.: The North American Soil Moisture Database: Development and Applications, B. Am. Meteorol. Soc., 97, 1441-1459, doi:10.1175/BAMS-D-1300263.1, 2016.

Renzullo, L. J., van Dijk, A. I. J. M., Perraud, J. M., Collins, D., Henderson, B., Jin, H., Smith, A. B., and McJannet, D. L.: Con- tinental satellite soil moisture data assimilation improves rootzone moisture analysis for water resources assessment, J. Hydrol., 519, 2747-2762, doi:10.1016/j.jhydrol.2014.08.008, 2014.

Robock, A., Luo, L., Wood, E. F., Wen, F., Mitchell, K. E., Houser, P. R., Schaake, J. C., Lohmann, D., Cosgrove, B., Sheffield, J., Duan, Q., Higgins, R. W., Pinker, R. T., Tarpley, J. D., Basara, J. B., and Crawford, K. C.: Evaluation of the North American Land Data Assimilation System over the southern Great Plains during the warm season, J. Geophys. Res.-Atmos., 108, 8846, doi:10.1029/2002JD003245, 2003.

Rötzer, K., Montzka, C., and Vereecken, H.: Spatio-temporal variability of global soil moisture products, J. Hydrol., 522, 187-202, doi:10.1016/j.jhydrol.2014.12.038, 2015.

Sanchez-Mejia, Z. M., Papuga, S. A., Swetish, J. B., van Leeuwen, W. J. D., Szutu, D., and Hartfield, K.: Quantifying the influence of deep soil moisture on ecosystem albedo: The role of vegetation, Water Resour. Res., 50, 4038-4053, doi:10.1002/2013WR014150, 2014.

Schaefer, G. L. and Paetzold, R. F.: SNOTEL (SNOwpack TELemetry) and SCAN (Soil Climate Analysis Network), Automated Weather Stations for Applications in Agriculture and Water Resources Management: Current Use and Future Perspectives, Lincoln, Nebraska, USA, 187-194, 2001.

Schaefer, G. L., Cosh, M. H., and Jackson, T. J.: The USDA Natural Resources Conservation Service Soil Climate Analysis Network (SCAN), J. Atmos. Ocean. Technol., 24, 2073-2077, doi:10.1175/2007JTECHA930.1, 2007.

Schroeder, J. L., Burgett, W. S., Haynie, K. B., Sonmez, I., Skwira, G. D., Doggett, A. L., and Lipe, J. W.: The West Texas Mesonet: A Technical Overview, J. Atmos. Ocea. Technol., 22, 211-222, doi:10.1175/JTECH-1690.1, 2005.

Scott, B. L., Ochsner, T. E., Illston, B. G., Fiebrich, C. A., Basara, J. B., and Sutherland, A. J.: New Soil Property Database Improves Oklahoma Mesonet Soil Moisture Estimates, J. Atmos. Ocean. Technol., 30, 2585-2595, doi:10.1175/JTECH-D-13-00084.1, 2013.

Seneviratne, S. I., Corti, T., Davin, E. L., Hirschi, M., Jaeger, E. B., Lehner, I., Orlowsky, B., and Teuling, A. J.: Investigating soil moisture-climate interactions in a changing climate: A review, Earth-Sci. Rev., 99, 125-161, doi:10.1016/j.earscirev.2010.02.004, 2010.

Seneviratne, S. I., Wilhelm, M., Stanelle, T., van den Hurk, B., Hagemann, S., Berg, A., Cheruy, F., Higgins, M. E., Meier, A., Brovkin, V., Claussen, M., Ducharne, A., Dufresne, J.-L., Findell, K. L., Ghattas, J., Lawrence, D. M., Malyshev, S., Rummukainen, M., and Smith, B.: Impact of soil moisture-climate feedbacks on CMIP5 projections: First results from the GLACECMIP5 experiment, Geophys. Res. Lett., 40, 2013GL057153, doi:10.1002/grl.50956, 2013.

Sheffield, J., Barrett, A. P., Colle, B., Fernando, D. N., Fu, R., Geil, K. L., Hu, Q., Kinter, J., Kumar, S., Langenbrunner, B., Lombardo, K., Long, L. N., Maloney, E., Mariotti, A., Meyerson, J. E., Mo, K. C., Neelin, J. D., Nigam, S., Pan, Z., Ren, T., RuizBarradas, A., Serra, Y. L., Seth, A., Thibeault, J. M., Stroeve, J. C., Yang, Z., and Yin, L.: North American Climate in CMIP5 Experiments, Part I: Evaluation of Historical Simulations of Continental and Regional Climatology, J. Climate, 26, 9209-9245, doi:10.1175/JCLI-D-12-00592.1, 2013. 
Srinivasan, G., Robock, A., Entin, J. K., Luo, L., Vinnikov, K. Y., and Viterbo, P.: Soil moisture simulations in revised AMIP models, J. Geophys. Res.-Atmos., 105, 26635-26644, doi:10.1029/2000JD900443, 2000.

Taylor, K. E.: Summarizing multiple aspects of model performance in a single diagram, J. Geophys. Res.-Atmos., 106, 7183-7192, doi:10.1029/2000JD900719, 2001.

Taylor, K. E., Stouffer, R. J., and Meehl, G. A.: An Overview of CMIP5 and the Experiment Design, B. Am. Meteorol. Soc., 93, 485-498, doi:10.1175/BAMS-D-11-00094.1, 2012.

Thomson, A., Calvin, K., Smith, S., Kyle, G. P., Volke, A., Patel, P., Delgado-Arias, S., Bond-Lamberty, B., Wise, M., Clarke, L., and Edmonds, J.: RCP4.5: a pathway for stabilization of radiative forcing by 2100 , Climatic Change, 109, 77-94, doi:10.1007/s10584-011-0151-4, 2011.

van den Hurk, B., Doblas-Reyes, F., Balsamo, G., Koster, R. D., Seneviratne, S. I., and Camargo, H.: Soil moisture effects on seasonal temperature and precipitation forecast scores in Europe, Clim. Dynam., 38, 349-362, doi:10.1007/s00382-010-0956-2, 2010.

Vivoni, E. R., Moreno, H. A., Mascaro, G., Rodriguez, J. C., Watts, C. J., Garatuza-Payan, J., and Scott, R. L.: Observed relation between evapotranspiration and soil moisture in the North American monsoon region, Geophys. Res. Lett., 35, L22403, doi:10.1029/2008GL036001, 2008.

Wanders, N., Karssenberg, D., Bierkens, M., Parinussa, R., de Jeu, R., van Dam, J., and de Jong, S.: Observation uncertainty of satellite soil moisture products determined with physically-based modeling, Remote Sens. Environ., 127, 341356, doi:10.1016/j.rse.2012.09.004, 2012.

Wang, J. K., Ford, T. W., and Quiring, S. M.: Distinguishing between Unorganized and Organized Convection When Examining Land-Atmosphere Relationships, J. Appl. Meteorol. Climatol., 54, 2229-2243, doi:10.1175/JAMC-D-15-0086.1, 2015.
Wetzel, P. J. and Chang, J.-T.: Concerning the Relationship between Evapotranspiration and Soil Moisture, J. Climate Appl. Meteorol., 26, 18-27, doi:10.1175/15200450(1987)026<0018:CTRBEA>2.0.CO;2, 1987.

Wu, L. and Zhang, J.: Asymmetric effects of soil moisture on mean daily maximum and minimum temperatures over eastern China, Meteorol. Atmos. Phys., 122, 199-213, doi:10.1007/s00703013-0284-2, 2013.

Xia, Y., Ek, M. B., Wu, Y., Ford, T., and Quiring, S. M.: Comparison of NLDAS-2 Simulated and NASMD Observed Daily Soil Moisture. Part II: Impact of Soil Texture Classification and Vegetation Type Mismatches, J. Hydrometeorol., 16, 1981-2000, doi:10.1175/JHM-D-14-0097.1, 2015a.

Xia, Y., Ek, M. B., Wu, Y., Ford, T., and Quiring, S. M.: Comparison of NLDAS-2 Simulated and NASMD Observed Daily Soil Moisture, Part I: Comparison and Analysis, J. Hydrometeorol., 16, 1962-1980, doi:10.1175/JHM-D-14-0096.1, 2015 b.

Xia, Y., Ford, T. W., Wu, Y., Quiring, S. M., and Ek, M. B.: Automated Quality Control of In Situ Soil Moisture from the North American Soil Moisture Database Using NLDAS-2 Products, J. Appl. Meteorol. Climatol., 54, 1267-1282, doi:10.1175/JAMCD-14-0275.1, 2015c.

Yuan, S. and Quiring, S. M.: Comparison of three methods of interpolating soil moisture in Oklahoma, International J. Climatol., 37, 987-997, doi:10.1002/joc.4754, 2016.

Zhang, L., Dawes, W. R., and Walker, G. R.: Response of mean annual evapotranspiration to vegetation changes at catchment scale, Water Resour. Res., 37, 701-708, doi:10.1029/2000WR900325, 2001. 